CELL BIOLOGY

\title{
Synthesis of 2'-5'-oligoadenylates and study of their effect on proliferation and migration of bone marrow stem cells of mice in vitro and in
} vivo

\author{
Z. Yu. Tkachuk, I. Ya. Dubey, T. G. Yakovenko, L. I. Semernikova, S. \\ O. Shapoval, V. S. Artemenko, L. V. Dubey
}

Institute of Molecular Biology and Genetics, NAS of Ukraine, 150, Zabolotny str., Kyiv, 03143, Ukraine

e-mail: ztkachuk@bigmir.net

\begin{abstract}
2'-5'-Triadenylate and its 3'-epoxy analogue were synthesized by phosphotriester method in solution. These compounds are shown to accelerate the migration of the bone marrow stem cells in donor mice and their inclusion into the spleen of recipient mice upon syngenic transplantation in vivo. 2'-5'-Oligoadenylates and their derivatives depending on their structure and concentration influence apoptosis and proliferation of mice bone marrow cells in vitro.
\end{abstract}

Keywords: 2'-5'-oligoadenylates, migration, oligonucleotide analogues, stem cells, proliferation, apoptosis.

Introduction. Nowadays special attention is paid to the studies on hematogenic stem cells due to their high proliferative activity and location in subendosteal region of the bone marrow. Most of them are pluripotent cells. The majority of stem cells is in $\mathrm{G}_{1}$ phase of cell cycle and has the capability for proliferation in specific microenvironment [1]. The hematopoietic cells are of significant practical importance in medicine for the treatment of malignant tumors and blood diseases [2].

(C) Z. YU. TKACHUK, I. YA. DUBEY, T. G. YAKOVENKO,

L. I. SEMERNIKOVA, S. O. SHAPOVAL, V. S. ARTEMENKO,

L. V. DUBEY, 2007
Bone marrow cells being injected in small amounts into the irradiated mice reach main hematopoietic organs, particularly the spleen. Proliferation of the injected hematopoietic cells there results in formation of hematopoietic colonies, discretely located along the spleen in the shapes of macroscopic knots, which in 7-10 days after transplantation contain several millions of hematopoietic cells [3]. Stimulating effect of some medications on proliferation of mice bone marrow stem cells has been described [4].

More intensive investigation of the preparations stimulating the proliferation of stem cells in 


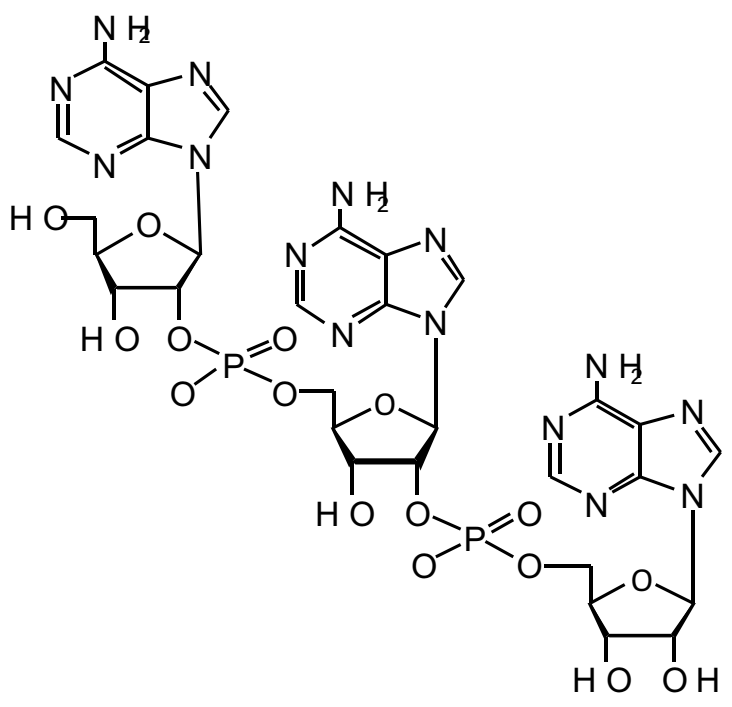

Adenylates structure

subendosteal area of bone marrow has started after discovering the role of stem cells in homeostasis. Most types of bone marrow stem cells are potentially capable of proliferating under favorable conditions [5].

Medical preparations that initiate the migration of bone marrow stem cells into bloodstream are being developed by Japanese researchers. They revealed that sympathetic nervous system can control the division of stem cells and proposed the medicine which restores and mobilizes the migration of stem cells of the organism by stimulating the activity of sympathetic nervous system [6].

Taiwanese scientists studied, in terms of efficiency and safety, the possibility of stroke treatment with granulocyte colony-stimulating factor (G-CSF) that mobilizes stem cells and demonstrates anti-inflammatory and neuroprotective activity. Clinical trials showed G-CSF treatment for acute ischemic stroke to be safe and favorably affecting the conditions of patients [7].

2'-5'-Oligoadenylates (2-5A) were shown to play the key role in the mechanism of antiviral activity of interferon, in the processes of cell growth and differentiation, diabetes and atherosclerosis pathogenesis, apoptosis etc. [8].

The deficiency of bone marrow stem cells occurs during the diseases connected with cytopenia of organs and tissues. It is applicable first of all to oncologic patients during chemotherapy, patients after long-lasting treatment with antibiotics, patients with

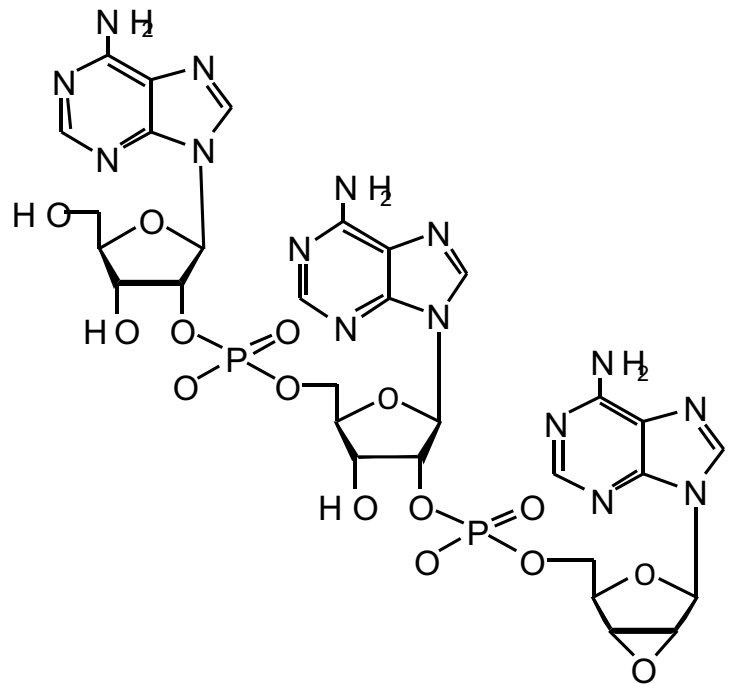

2

protracted chronic diseases and immunological disorders. In all of these cases, the prolonged suppression of division of bone marrow stem cells is observed [9]. There is a great need in increased migration of bone marrow stem cells during myocardial infarction, stroke, arthritis etc.

Unfortunately, natural adenylate 1 (Figure) is rapidly destroyed in the cell by phosphodiesterases. 2'-5'A analogues often demonstrate increased biological activity. A significant number of 2'-5'A analogues modified at sugar residues, internucleotide phosphates and heterocyclic bases have been obtained. 2'-5'-Triadenylate analogue 2 containing epoxyadenosine residue at 3'-end (epoxy-2-5A) was shown to be the effective inhibitor of transplanted tissues rejection [10], and to possess cardioprotective activity [11].

The aim of current work was to investigate the effect of synthesized 2'-5'-oligoadenylates and their analogues on the enrichment of blood with stem cells. We supposed that the proposed preparations could influence in vitro proliferation and in vivo proliferation and migration of stem cells during syngenic transplantation and thereby help the organism to reimburse the deficiency of stem cells.

Materials and Methods. Chemical synthesis of oligoadenylates Adenosine, 4,4'-dimethoxytrityl chloride (DMTrCl), 2-chlorophenyl dichlorophosphate, triisopropylbenzenesulfonyl 
chloride (TPSCl) (Aldrich, Germany) and reagents and solvents of domestic origin were used for the synthesis of trimers. Acetonitrile was distilled over $\mathrm{P}_{2} \mathrm{O}_{5}$ and calcium hydride; pyridine was dried by distillation over $\mathrm{NaOH}$, ninhydrin and calcium hydride. UV spectra were recorded using Specord UV-Vis spectrophotometer (Karl Zeiss Jena, Germany). Thin layer chromatography was performed on Silica gel $60 \mathrm{~F}_{254}$ plates (Merck, Germany) in the following systems: chloroform-methanol $9: 1 \quad(A)$ and isopropanol-concentrated $\mathrm{NH}_{3}$-water 5:1:2(B).

6-N,3'-O-dibenzoyl-5'-O-dimethoxytrityladenosin e-2'-O-(2-chlorophenyl)phosphate 3 (Scheme) was obtained from 6-N,3'-O-dibenzoyl-5'-O-dimethoxytrityladenosine [12] in accordance with the standard phosphorylation method [13].

6-N-benzoyl-9-(2,3-anhydro- $\beta$-D-ribofuranosyl)ad enine $\mathbf{4}$ was synthesized using selective benzoylation of 2',3'-anhydroadenosine [14] according to the method described in [10].

Adenylyl-(2'-5')-adenylyl-(2'-5')-(2',3'-anhydroade nosine) 2. Nucleotide component 3 (1.34 g, 1.25 $\mathrm{mmol}$ ), nucleoside component 4 ( $353 \mathrm{mg}, 1 \mathrm{mmol})$, and $\mathrm{N}$-methylimidazole $(750 \mathrm{mkl}, 9.4 \mathrm{mmol})$ were co-evaporated with absolute pyridine $(2 \times 10 \mathrm{ml})$, then dissolved in $10 \mathrm{ml}$ of absolute pyridine and TPSCl was added $(948 \mathrm{mg}, 3.13 \mathrm{mmol})$. In $10 \mathrm{~min}$ the reaction mixture was diluted with $50 \mathrm{ml}$ of chloroform and washed with aqueous solution of sodium bicarbonate (2 x $30 \mathrm{ml})$ and water $(30 \mathrm{ml})$, organic layer was dried over anhydrous $\mathrm{Na}_{2} \mathrm{SO}_{4}$ and evaporated in vacuum. Pyridine excess was removed by evaporating with toluene $(2 \mathrm{x}$ $10 \mathrm{ml}$ ). Fully protected dinucleotide $\mathbf{5 a}$ was isolated by silica gel chromatography in the gradient of methanol in chloroform $(0-3 \%)$. Fractions containing the product were evaporated. $1.10 \mathrm{~g}$ of dimer $\mathbf{5 a}$ (yield $85 \%$ ) was obtained as a white foam. The product was dissolved in $75 \mathrm{ml}$ of $2 \%$ solution of $p$-toluenesulfonic acid in chloroform-methanol $(9: 1)$ mixture. In $5 \mathrm{~min}$ the reaction mixture was diluted with $50 \mathrm{ml}$ of chloroform and washed with aqueous $\mathrm{NaHCO}_{3}(3 \times 50 \mathrm{ml})$ and water $(50 \mathrm{ml})$, organic layer was dried with $\mathrm{Na}_{2} \mathrm{SO}_{4}$ and evaporated. Detritylated dimer $\mathbf{5 b}$ was isolated by silica gel chromatography in the gradient of methanol (0-3\%) in chloroform. Corresponding fractions were evaporated to give $764 \mathrm{mg}$ of white foam $(90 \%)$.
$764 \mathrm{mg}$ of dimer $\mathbf{5 b}(0.76 \mathrm{mmol})$ were condensed with $1.01 \mathrm{~g}$ of nucleotide component $3(0.95 \mathrm{mmol}$, 1.25 eq.) in the presence of $570 \mathrm{ml}(7.14 \mathrm{mmol})$ of MeIm and $721 \mathrm{mg}$ of TPSCl $(2.38 \mathrm{mmol})$, and then the isolated fully protected trimer $(0.62 \mathrm{mmol}, 81 \%)$ was detritylated as described above. $898 \mathrm{mg}$ of the white foam of detritylated trinucleotide $(0.54 \mathrm{mmol}$, yield $87 \%$ ) were obtained. It was dissolved in the mixture of dioxane and concentrated $\mathrm{NH}_{3}(2: 3,100 \mathrm{ml})$ and kept for 3 days at room temperature. The solution was evaporated, and the residue was partitioned between 25 $\mathrm{ml}$ of $0.01 \mathrm{M}$ triethylammonium bicarbonate (TEAB, $\mathrm{pH} 7.5$ ) and $25 \mathrm{ml}$ of $\mathrm{CHCl}_{3}$. Aqueous layer was separated and applied on a column with Moleselect DEAE-25 sorbent (Reanal, Hungary) in $\mathrm{HCO}_{3}^{-}$form. The product was isolated in the gradient $(0.01-0.3 \mathrm{M})$ of TEAB, $\mathrm{pH}$ 7.5. The desired fractions were evaporated with ethanol, the product was dissolved in ethanol $(25 \mathrm{ml})$ and precipitated with $250 \mathrm{ml}$ of saturated KI solution in acetone. The precipitate was filtered off, washed with acetone $(5 \times 5 \mathrm{ml})$ and hexane $(3 \times 5 \mathrm{ml})$ and dried in vacuum to give a white powder of potassium salt $2(234 \mathrm{mg}, 0.24 \mathrm{mmol}$, yield after deblocking $45 \%$; total yield $24 \%$ based on OH-component 4 introduced into the synthesis). $\mathrm{R}_{\mathrm{f}}$ 0.72 (system B). UV $\left(\mathrm{H}_{2} \mathrm{O}\right): \lambda_{\max }=259 \mathrm{~nm}(\varepsilon=$ $\left.3.73 \mathrm{C} 10^{4}\right)$.

Natural trimer $2^{\prime}-5^{\prime} A_{3} 1$ was obtained in accordance with the above method with an overall yield $26 \%$ from starting $\mathrm{OH}$-component. The latter in this case was $2^{\prime}, 5^{\prime}, \mathrm{N}$-protected adenosine prepared as described in [12]. Product 1 is a white powder, $\mathrm{R}_{\mathrm{f}} 0.70$ (system $\mathrm{B}$ ). $\mathrm{UV}\left(\mathrm{H}_{2} \mathrm{O}\right): \lambda_{\max }=259 \mathrm{~nm}\left(\varepsilon=3.76 \mathrm{C} 10^{4}\right)$.

Biological experiments. The method used in this work was developed in [15]. Male and female mice of mouse line Black C57j were used in the experiments. Male mice (375 animals) were chosen to be the recipients and female mice were donors of bone marrow cells (BMC).

In order to inhibit their own immune system and hemopoiesis male recipients were X-rayed. The irradiation was performed using X-ray system RUM-17, absorpbed dose was $6 \mathrm{~Gy}(200 \mathrm{kV}, 5.0 \mathrm{~mA}$, focus distance $50 \mathrm{~cm}$, filters: $\mathrm{Cu}-0.5 \mathrm{~mm}, \mathrm{Al}-1.0 \mathrm{~mm}$, locally).

Oligoadenylates were introduced into recipient mice orally in various concentrations. In 1-1.5 h, the 
mice were put to sleep using ether and bone marrow was quickly isolated from thigh bones. The animal was fastened to a dissection board. Mouse skin was treated with alcohol, especially the back leg from which the bone marrow was isolated. The thigh skin was cut with small sterile scissors and thigh bone with epiphysis was taken out, cleaned of muscles and cut at both joint ends. All procedures were performed in cold place under sterile box conditions. Then, $1 \mathrm{ml}$ of Hanks' solution for cell culture without dye was placed into the small sterile flask. Bone marrow was washed off from the bone into this flask using Hanks' medium-filled syringe with a medullar hollow needle, diameter of the latter matching the diameter of bone marrow channel. The bone marrow was suspended with the same syringe by filling and emptying it several times to disaggregate the tissues. The suspension passed slowly through the syringe, in order to keep low pressure inside the syringe. One mouse thigh bone contains $\sim 1 \mathrm{C} 10^{7}$ of BMC [16]. BMC amount was calculated in the obtained suspension, for that $10 \mathrm{mkl}$ of Trypan Blue or Gentian Violet solution and $10 \mathrm{mkl}$ of BMC suspension were loaded into the well of the plate used for viral investigations and mixed. BMC amount in 20 large cells of Goryaev's apparatus was counted under microscope, and total amount in $1 \mathrm{ml}$ of the solution was calculated using the formula accepted in clinical research [17]. BMC concentration necessary for injection into the recipients was $0.7510^{5}$ cells in $1 \mathrm{ml}$. After determining total BMC amount in suspension it was diluted with a physiological solution accordingly.

In 2-3 hours upon irradiation, the recipients were injected with $100 \mathrm{mkl}$ of BMC suspension via eye venous sinus.

After BMC introduction the recipients were placed into clean cages according to variants. As the mice were weakened by irradiation, they were given nourishing high-calorie food and acidified boiled water $(2 \mathrm{ml} 0.1 \mathrm{~N}$ $\mathrm{HCl}$ per $100 \mathrm{ml}$ of water) containing antibiotic (cefazoline, $100 \mathrm{mg}$ per $100 \mathrm{ml}$ of water) to prevent intestinal diseases.

On the $8^{\text {th }}$ day after BMC introduction the mice were killed, then after careful midline abdominal incision, the spleen was isolated, put into Clarke's solution (1 volume of concentrated acetic acid per 3 volumes of ethyl alcohol) to dissolve erythroid cells. Next day the spleens were taken out of Clarke's solution and the number of stem cell colonies was calculated using a magnifying glass. Light grumous colonies were observed on dark spleen background. The number of these colonies can provide the information on the number of colony-forming units in stromal tissue.

To study the influence of 2'-5'-oligoadenylates and their analogues on apoptosis and proliferation of BMC in vitro only mice of C57B1/6 line, weight $18-25 \mathrm{~g}$, have been used. Induced proliferation was investigated by cultivating the cell suspension in $\mathrm{CO}_{2}$ incubator for 3 days in penicillin vials in RPMI medium containing $300 \mathrm{mkg} / \mathrm{ml}$ of glutamine, $100 \mathrm{mkg} / \mathrm{ml}$ of gentamycin and $10 \%$ calf embryonic serum.

Phytohemagglutinine (PHA, Sigma, USA) in the concentration of $30 \mathrm{mkg} / \mathrm{ml}, 2^{\prime}-5^{\prime} \mathrm{A}_{3} \mathbf{1}$ in the concentrations of $10^{-6}, 10^{-7}, 10^{-8} \mathrm{M}$, and $2^{\prime}-5^{\prime}-$ epoxy- $\mathrm{A}_{3} 2$ in the concentrations of $10^{-5}, 10^{-6}, 10^{-7} \mathrm{M}$ were used as stimulators of cell proliferation. Control samples were incubated in RPMI medium without any substances added.

Cell distribution by the phases of mitotic cycle was analyzed using the flow cytometry method. At least 20,000 cells of 10 mice have been analyzed for each variant. The cells were stained with propidium iodide. In 3 days the cells were removed from flasks and put into cytofluorimetric vials $\left(10^{6}\right.$ per sample), centrifuged at 200 $\mathrm{g}$ for $10 \mathrm{~min}$, resuspended in $200 \mathrm{mkl}$ of buffered physiological solution, $300 \mathrm{ml}$ of homotonic lysing buffer $(0.1 \%$ sodium citrate, $0.1 \%$ triton $\mathrm{X}-100$, and $10 \mathrm{ml}$ of propidium iodide solution, all reagents from Sigma). After gentle stirring, the cells were incubated at $22-25^{\circ} \mathrm{C}$ for 30 min in the dark. Proliferative activity index (PAI) was determined using the commonly known formula:

$$
P A I=\frac{\% \text { cell in }(G 2+M+S) \text { phases }}{\% \text { cell in apoptpsis }}
$$

All cytometric investigations were performed on FACSCan (Becton Dickinson, USA) equipped with argon laser (wavelength $488 \mathrm{~nm}$ ).

To collect and analyze the data Cell Quest for Mac software was used. The cell cycle phase distribution was additionally analyzed with Mod Fit LT 2.0 software.

Statistical analysis of the results was performed using Student's $t$-criterion.

Results and Discussion. Usually one of the variants of phosphotriether synthesis in the solution is used for 


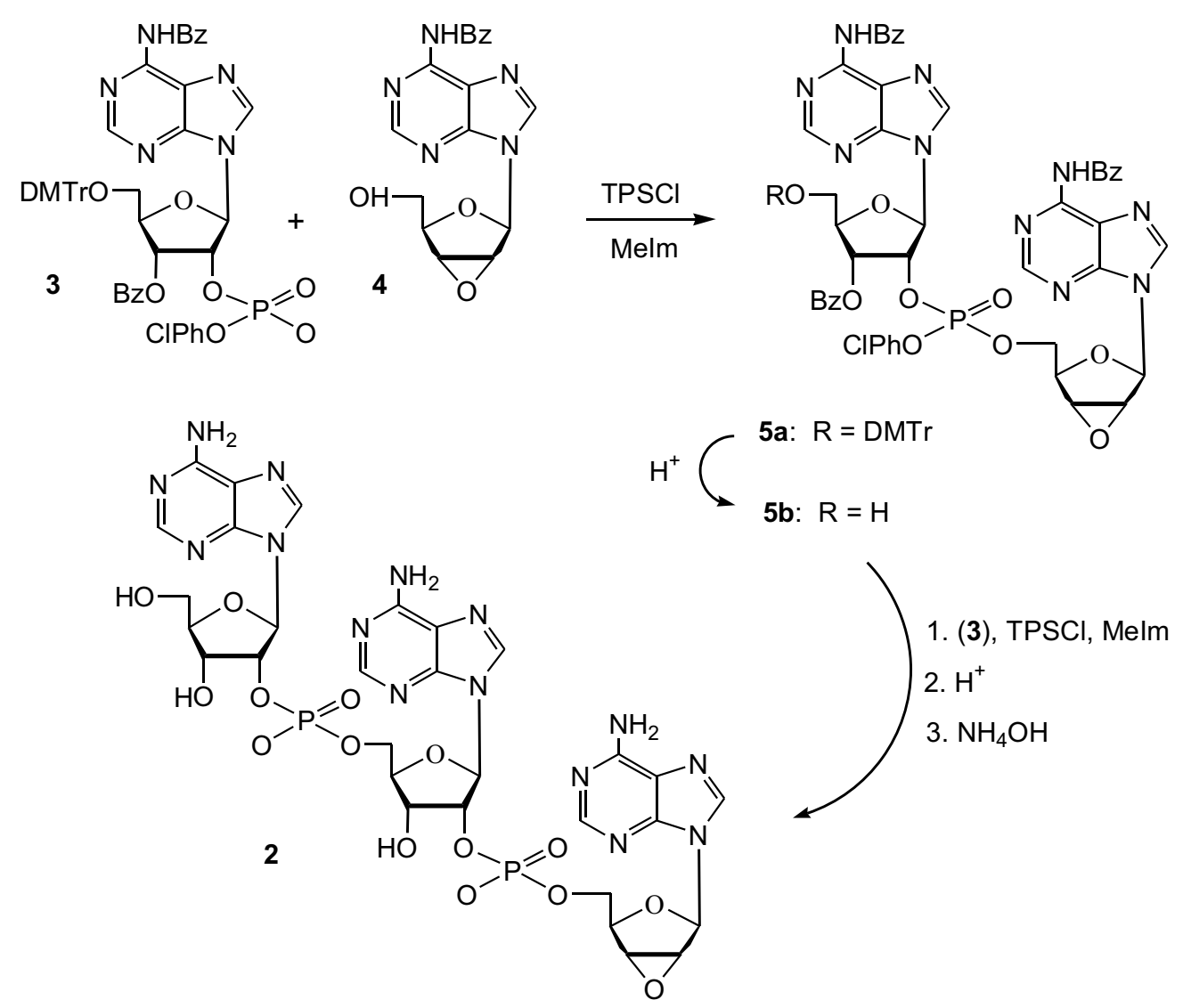

Scheme. Synthesis of 3'-epoxy-modified 2'-5'-triadenylate Bz - benzoyl, DMTr - dimethoxytrityl, MeIm - N-methylimidazole, TPSCl 2,4,6-triisopropylbenzenesulfonyl chloride

the preparation of 2'-5'-oligoadenylates and their analogues. We have developed a convenient method of synthesis of 2'-5'-tiradenylate containing epoxy group at 3 -end (Scheme). Trinucleotide 2 was obtained by common method of oligonucleotide synthesis using condensing reagent triisopropylbenzenesulfonyl chloride (TPSCl) in the presence of N-methylimidazole (MeIm) as a nucleophilic catalyst of internucleotide coupling reaction [18].

N,5',3'-O-protected adenosine-2'-phosphodiester 3 was used as nucleotide component of oligonucleotide synthesis. 3'-Terminal nucleoside component for epoxy analogue synthesis was 6-N-protected 2',3' -anhydroadenosine 4. Three equivalents of nucleophilic catalyst with respect to condensing reagent and $25 \%$ excess of P-component $\mathbf{3}$ over nucleoside component were introduced into the coupling reactions in epoxy-2' $-5^{\prime} \mathrm{A}_{3}$ triadenylate synthesis from syntons 3 and 4 . The coupling reactions were fast $(10 \mathrm{~min})$ and with a high yield $(80-85 \%)$. The reaction products were isolated by preparative chromatography on silica gel throughout the synthesis. After the complete removal of protective groups, trimer $\mathbf{2}$ was purified by anion exchange chromatography. The yield of the modified triadenylate 2 was $24 \%$ from starting nucleoside component 4.

Non-modified "core" 2'-5' $\mathrm{A}_{3} \mathbf{1}$ was synthesized in the similar way. In this case, 2',3'-N-protected adenosine [12] was used as 3'-terminal nucleoside component of synthesis. The yield of natural trimer $2^{\prime}-5 \mathrm{~A}_{3}$ was $26 \%$ based on the starting $\mathrm{OH}$-component.

Potassium salts of 2 -5 -triadenylates were used for biological experiments. The purity of obtained compounds exceeded $95 \%$, according to HPLC data.

The influence of 2'-5'-oligoadenylate and epoxy derivative on apoptosis and proliferation of BMC of C57B1/6 mouse cell line in vitro was studied in the first series of experiments. The results of this study are shown in Table 1.

As it can be seen from the data presented in Table 1, the effect of 2'-5'-oligoadenylates and their analogues 
Table 1.

Influence of 2'-5'-triadenylate 1 and its epoxy derivative 2 on apoptosis and proliferation of BMC in C57B1/6 mouse cell line in vitro

\begin{tabular}{|c|c|c|c|c|c|}
\hline Preparation & Concentration & \multicolumn{4}{|c|}{$\mathrm{BMC}, \%$} \\
\hline RPMI & Control & $44,7 \pm 2,3$ & $18,28 \pm 0,49$ & $0,41 \pm 0,001$ & - \\
\hline PHA & $30 \gamma / \mathrm{ml}$ & $39,48 \pm 1,13$ & $20,52 \pm 1,43$ & $0,517 \pm 0,022$ & - \\
\hline (1) & $10^{-6} \mathrm{M}$ & $26,45 \pm 3,37$ & $28,77 \pm 2,23$ & $1,054 \pm 0,1$ & 0,99 \\
\hline (1) & $10^{-8} \mathrm{M}$ & $27,9 \pm 2,72$ & $26,22 \pm 1,3$ & $0,81 \pm 0,06$ & 0,99 \\
\hline (2) & $10^{-5} \mathrm{M}$ & $23,7 \pm 2,07$ & $29,3 \pm 1,4$ & $1,42 \pm 0,1$ & 0,99 \\
\hline (2) & $10^{-6} \mathrm{M}$ & $36,7 \pm 1,1$ & $48,68 \pm 3,57$ & $1,38 \pm 0,15$ & 0,99 \\
\hline
\end{tabular}

Table 2.

Influence of 2'-5'-triadenylate 1 and its epoxy derivative 2 on the number of stem cells colonies in vivo

\begin{tabular}{l|c|c|c|c|c|c}
\hline \multicolumn{1}{c}{ Variant } & $\mathrm{M}$ & $\%$ & $\delta$ & $\mathrm{m}$ & Td & \\
\hline Control & 9.23 & 100 & 6.80 & 1.7 & 4.00 & $\mathrm{P}=0.99$ \\
$(\mathbf{1}), 10^{-5} \mathrm{M}$ & 9.25 & 208 & 7.80 & 1.70 & 3.00 & $\mathrm{P}=0.99$ \\
$(\mathbf{1}), 10^{-6} \mathrm{M}$ & 18.00 & 196 & 7.80 & 2.50 & 3.70 & 2.60 \\
$(\mathbf{2}), 10^{-5} \mathrm{M}$ & 19.70 & 213 & 8.10 & 0.89 & $\mathrm{P}=0.99$ \\
$(\mathbf{2}), 10^{-6} \mathrm{M}$ & 10.80 & 117 & 2.13 & & 0.84 & not trustworthy \\
\hline
\end{tabular}

on apoptosis and proliferation of BMC depends on the dose. Natural 2'-5'-oligoadenylate in the concentration $10^{-6} \mathrm{M}$ inhibits apoptosis in the investigated cells almost 2 times and in the concentrations $10^{-7}-10^{-8} \mathrm{M}$ its influence decreases. The mentioned preparation stimulates BMC proliferation 1.5 times comparing to the control samples in all investigated concentrations. Natural "core" analogue, epoxy-2'-5'-triadenylate, also inhibits apoptosis in BMC. At concentration $10^{-5} \mathrm{M}$ the apoptosis level decreases twice. The level of proliferation increases at concentration $10^{-6} \mathrm{M}$, and corresponding PAI index increases more than twice.

Therefore, epoxy-analogue of 2'-5'-oligoadenylate differs from the natural "core" by its higher activity regarding apoptotic and proliferative processes in BMC.

The second series of experiments was devoted to the study of the influence of $2^{\prime}-5$ '-triadenylate $\mathbf{1}$ and its $3^{\prime}$-epoxy derivative 2 at the concentrations $10^{-5}$ and $10^{-6}$ $\mathrm{M}$ on the migration of mice stem BMC at syngenic transplantation. During these experiments $100 \mathrm{mkl}$ of preparations per mouse were introduced orally to female donors. The results of the experiments are presented in Table 2.
Table 2 presents the data on the influence of natural $2^{\prime}-5^{\prime} \mathrm{A}_{3} 1$ and its epoxy derivative 2 at $10^{-5}-10^{-6} \mathrm{M}$ concentrations with oral introduction to donors. Natural "core" at the concentration $10^{-5} \mathrm{M}$ is shown to stimulate proliferation of stem BMC more than two times comparing to control. At the concentration $10^{-6} \mathrm{M}$ it increases migration of stem BMC almost twice, that can be concluded from the increase of number of colonies formed in spleens of donor mice. Preparation 2 at the concentration $10^{-5} \mathrm{M}$ stimulates BMC proliferation and the number of cells increases more than two times. The same preparation at the concentration $10^{-6} \mathrm{M}$ does not influence the migration of stem BMC and the number of colonies in spleen of recipient mice, which is not very different from control samples.

2'-5'-oligoadenylate is closely connected with cAMP (cyclic adenosine monophosphate) system in the cell [19]. The effect of proliferation inductors and cyclic nucleotides depends on $\mathrm{Ca}^{2+}$ ions concentration. In [20], $\mathrm{Ca}^{2+}$ was shown to be the important regulation factor of cell proliferation, including blood-forming stem cells. As 2-5A system is connected with cAMP and cGMP, stimulated action of oligoadenylates and 
their analogues can be supposed to depend on $\mathrm{Ca}^{2+}$ metabolism in the cell.

Conclusions. The results of the experimental work allow to conclude that the introduction of natural "core" $2^{\prime}-5{ }^{\prime} \mathrm{A}_{3}$ and its 3 '-epoxy derivative stimulates the migration of stem bone marrow cells and influences apoptosis and proliferation of BMC in vitro. The effect of these preparations depends on their concentration. Therefore, we consider 2'-5'-oligoadenylates and their derivatives to be promising preparations for the treatment of cancer and blood diseases.

3. Ю. Ткачук, И. Я. Дубей, Т. Г. Яковенко, Л. И. Семерникова, С. А. Шаповал, В. С. Артеменко, Л. В. Дубей

Синтез 2'-5'-олигоаденилатов и их влияние на пролиферацию и миграцию стволовых клеток костного мозга мышей in vitro и in vivo

Резюме

Фосфотриэфирным методом в растворе синтезированы 2'-5 '-триаденилат и его 3 '-эпоксианалог. Установлено, что эти препараты стимулируют миграчию стволовых клеток костного мозга мылшей-доноров и их включение в селезенку мышей-реципиентов при сингенной трансплантации іп vivo. 2'-5'-олигоаденилаты и их производные в зависимости от препарата и его кониентрачии влияют на апоптоз и пролиферацию клеток костного мозга мышей in vitro.

Ключевые слова: 2'-5'-олигоаденилаты, аналоги олигонуклеотидов, миграция, стволовые клетки, пролиферачия.

\section{REFERENCES:}

1. Домкус В.С., Домкене В.А., Шемкявичене В.И. и др. Действие некоторых препаратов на стволовые кроветворные клетки // Сб. “Стволовые клетки и опухолевый рост". Киев, Наукова думка, 1985, с. 238-239.

2. Лукаш Л.Л., Василовская С.В. Стволовые клетки in vitro как основа для создания современных технологий // Биополимеры и клетка, 2001, т. 17, № 3, с. 203-211.

3. Гурвич А.Е., Егоров И.К., Кяйвяряйнен А.И. и др. Проблемы биологии развития. Иммуногенез и клеточная дифференцировка. М., Наука, 1978, с. 103.

4. Фриндель Э. Факторы стимулирующие и ингибирующие костномозговые стволовые клетки мышей // Сб. “Стволовые клетки и опухолевый рост”. Киев, Наукова думка, 1981, с. 45-53.

5. Player M.R., Torrence P.F. The 2-5A system: modulation of viral and cellular processes through acceleration of RNA degradation // Pharmacol. Ther., 1998, v. 78, No. 2, p. 55-113.

6. Katayama Y., Batista M., Kao W.M., Hidalgo F., Pierec A.I., Thomas S.A., Frenette P.S. Signals from the sympathetic nervous system regulate hematopoietic stem and progenitor cell egress from bone marrow. // Cell, 2006, v. 124, No. 2, p. 407-421.

7. Shyu W.C., Lin C.C.,Liu D.D., Li H. Granulocyte colony-stimulating factor for acute ischemic stroke: a randomized controlled trial //Can. Med. Ass. J., 2006, v. 174, No. 7, p. 927-933.

8. Adah S.A., Bayly S.F., Cramer H., Silverman R.H., Torrence P.F. Chemistry and biochenistry of 2',5'-oligoadenylate-based antisense strategy // Curr. Med. Chem., 2001, v. 8, No. 10 , p. 1189-1212.

9. Запорожан В.Н.,. Бажсра Ю.И. Стволовые клетки. O., 2004 , c. 227.

10. Tkachuk Z, Kvasyuk E., MatsukaG., Mikhailopulo I. (2'-5')Oligoadenylate analogues useful as inhibitors of host-vs.-graft responce. United States Patent 5571799, 1996.

11. Сидорик Л.Л., Дубей И.Я., Бобык В.И., Козлов А.В., Федоркова О.М., Ковеня Т.В., Рябенко Д.В., Сергиенко О.В., Трунина И.В., Погребной П.В., Мачука $\Gamma . X$. Терапевтические эффекты действия различных доз 2'-5'-олигоаденилата при экспериментальном миозин-индуцированном повреждении миокарда // Доповіді НАН України, 2001, № 9, с. 161-165.

12. Kvasyuk E.I., Kulak T.I., Khripach N.B., Mikhailopulo I.A., Uhlmann U., Charubala R., Pfleiderer $W$. Nucleotides XXIV. Preparative synthesis of trimeric (2'-5')oligoadenylic acid // Synthesis, 1987, p. 535-541.

13. Oligonucleotide synthesis: a practical approach / Ed. M.J. Gait. Oxford: IRL Press, 1984. 218 p.

14. Robins M.J., Fouron Y., Mengel R. Nucleic acid related compounds. 11. Adenosine 2',3'-ribo-epoxide. Synthesis, intramolecular degradation and transformation into 3'-substituted xylofuranosyl nucleosides and lyxo-epoxide // J. Org. Chem., 1974, v. 39, No.11, p. 1564-1570.

15. Till J.E, McCulloch E.A. A direct measurement of the radiation sensitivity of normal mouse bone marrow cells // Radiat Res., 1961, v. 14, No. 2, p. 213-222.

16. Кузнеиов С.A. Поддержание кроветворения и лимфопоэза в культурах на стромальных подложках // Сб. “Методы культивирования клеток”. Л., Ленинградское отделение “Наука”, 1988, с. 267.

17. Справочник по клиническим лабораторным методам исследования / Под ред. Е.А. Кост., М., Медицина, 1975 , с. 22-23.

18. Efimov V.A., Buryakova A.A., Reverdatto S.V., Chakhmakhcheva O.G., Ovchinnikov Yu.A. Rapid synthesis of long-chain deoxyribooligonucleotides by the N-methylimidazolide phosphotriester method // Nucleic Acids Res., 1983, v. 11, No. 23, p. 8369-8387.

19. Ткачук 3.Ю., Ткачук В.В.,Ткачук Л.В., Семерникова Л.І., Мацука Г.Х. Вплив 2'-5' олігоаденілатів та їх аналогів на рівень циклічних нуклеотидів в системах in vivo та in vitro // Біополімери і клітина, 2001, т. 17, №5, с. 411-416.

20. Федоров Н.А. Циклические нуклеотиды и лейкогенез // Сб. "Стволовые клетки и опухолевый рост”. Киев, Наукова думка, 1981, с. 110-119. 